\title{
The art of non-asserting: dialogue with Nāgārjuna
}

\author{
Marie-Hélène Gorisse \\ Department of Philosophy \\ University of Lille, France
}

\begin{abstract}
In his excellent paper, Nāgārjuna as anti-realist, Siderits showed that it makes sense to perform a connection between the position of the Buddhist Nāgārjuna and contemporary anti realist theses such as Dummett's one. The point of this talk is to argue that this connection is an important one to perform for one's correct understanding of what Nāgārjuna is doing when he criticizes the contemporary Indian theories of knowledge and assertion, first section, but as soon as the theories of argumentation are involved, this connection can be implemented in a better way from an other anti realist perspective, namely the one of Dialogical logic (Erlangen school), in which the signification is given in terms of rules in a language game.

The philosophical issues are to hold an interpretation of the type of assertion performed by Nāgārjuna. We here aim at making a rational reconstruction of his chief claim 'I do not assert any proposition' in which a proposition is considered as the set of its strategies of justification.

As for the last section, the point will be to apply these analyses to Buddhist practice. We will in this section consider the conventional character of human activities as the fact that any speech act is performed within a dialogue under ad-hoc restrictions; and the question of one's progress in the soteriological path to liberation will be asked ${ }^{1}$.
\end{abstract}

\section{Nāgārjuna on theories of knowledge}

\subsection{The dependent origination : an all-inclusive version of causation}

Nāgārjuna, one of the most influential thinkers of Buddhism and the founder of the mādhyamika school, the school of the Way of the Middle, developed in the second century AC a criticism of the contemporary Indian theories of knowledge and assertion. The key-concept of these criticisms is the concept of 'DEPENDENT ORIGINATION' (pratìtya-samutpāda) as taught in the sūtras of the prajñ $\bar{a}-p \bar{a} r a m i t \bar{a}$, the 'Perfection of Wisdom'. The dependent origination is a technical Buddhist expression involving particular definitions of the notions of causality and contingency: there is not a chain but a web of causation such that the existence of a thing is contingent upon the existence of every other thing.

\footnotetext{
${ }^{1}$ I would like to keenly thanks all members of the referee, which have helped me a lot throughout this reconstruction of Nāgārjuna's thought.
} 
For example, the existence of a tree is dependent upon the existence of a seed and upon the existence of wind, water, ground, and so on. In turn, the existence of the seed itself is also dependent upon the existence of the tree from which it comes and upon the existence of wind, water, ground, and so on. The list of the causes and conditions of existence of a thing can never be ended. Now, this tree is, in Nāgārjuna's perspective, nothing but the set of its conditions of existence. Thinking that there is an independent tree is thinking that there is a closed set of such conditions of existence, which is misleading. The Buddhists tell us that we have to think of reality as a generalized web of such dependencies and that the task of enunciating them is a never-ending task.

\subsection{The epistemic level}

The question therefore arises concerning everyday life practice: how is it that we do talk about the world and that we do have knowledge that governs our practice? The Buddhist answer amounts to saying that there is a decision from the knowing subject to carve out in the generalized web of interdependencies that she will call 'an object'. Therefore, she is always engaged within the choices she has made when she perceived. From this, her own conceptions are always engaged when she knows a fact of the world. In other words, the facts of the world and the knowledge I have of them can in no way be independent from each other. As Jay Garfield ${ }^{2}$ puts it:

To say that an object lacks essence, the Madhyamika philosopher will explain, is to say, as the Tibetans like to put it, that it does not exist

"from its own side" [...] that its existence depends upon us as well.

Now, one of the great consequences of the fact that my knowledge depends on the context in which it has been gained is that there is no such context as the universal one, in which the proposition at stake could have been firmly established. In other words, every proposition can be questionable from a different perspective. This is the main observation that is pointed out in the chief work of Nāgārjuna, namely, the Mūla-madhyamaka-kārika, the 'Fundamental Stances of the Middle Way'. In this work, he shows for each universally alleged knowledge statement of an other Indian school of thought that it is questionable.

We immediately understand that the statement saying that 'every proposition can be disputable from an other perspective' is itself disputable. This is essentially in order to avoid this type of criticisms that Nāgārjuna wrote the Vigrahavyāvartan̄, the 'Treatise to Prevent from Vain Discussions'. But in these lines, he supplies with an answer to these criticisms far much interesting than the classical problem of self reference. We here aim at a rational reconstruction of the strategy of Nāgārjuna in this work.

\footnotetext{
$\overline{2}$ In [4], p.220.
} 


\section{Nāgārjuna on theories of assertion}

In the Vigraha-vyāvartan $\bar{\imath}$ Nāgārjuna does not implement his ideas directly with regard to the process of acquisition of knowledge, but to the process of assertion and negation of a given thesis within a debate. The link between the two could easily be reformulated in the following way: the justification of an assertion in a philosophical debate is but the demonstration of the fact that what is asserted is rationally guaranteed, that is to say that it is the subject of knowledge.

\subsection{The art of making no assertion}

A new approach to knowledge statements First of all, let us examine again the dependency between my beliefs and the facts of the world. In order to have a better idea of what is at stake, let us focus on current theories that deal with similar conceptions, notably the anti realist position. Anti realist philosophers claim that, since there is no transcendent state of affairs, being epistemically guaranteed can not amount to being in adequacy with reality. The same important consequence has to be drawn from the Nāgārjunian conception, according to which I can not know something that exists independently of my knowledge of it. From this, Nāgārjuna is committed to the position that it is possible to give an account for the process of acquisition of knowledge that is different from the account in terms of adequacy with reality. And this precisely because we can never be sure of what is reality per se.

At a second stage, anti realist philosophers developed a new conception of knowledge according to which being epistemically guaranteed amounts to being justifiable. Here, the justification of knowledge is a conventional matter, it is a coherentist and not a foundationalist process and allows for a plurality of justified types of knowledge. In terms of assertion, this means that ' $\varphi$ is true' means ' $\varphi$ is justifiable'. And the semantic anti realist position is leading to the recognition of a plurality of ways in which an assertion can be said to be 'justifiable'.

Our claim is that Nāgārjuna speaks in terms of justification too. Notably because Nāgārjuna is in line with the Indian tradition of argumentation:

- First of all, the structure itself of the Vigraha-vyāvartan̄ is argumentative. More precisely, no position is put forward without its set of justifications. What is more, these justifications consist in the answer to all potential attacks of a conceivable opponent.

- Moreover, within the classical Indian tradition, something is admitted as knowledge if and only if it has been gained by means of a pramāna, a 'criterion for justified knowledge'. As argued, successfully in my view, by Siderits in [9] and by Waldo in [11], Nāgārjuna does not in the Vigraha-vyāvartan $\bar{\imath}$ call into question the possibility but the uniqueness of the pramāna account. Actually, Nāgārjuna is himself using pramāna. What is interesting for our subject is that this theory of pramāna has its roots within a theory of CONSENSUs. More precisely, the Naiyāyikas, who are the main interlocutors of 
Nāgārjuna in the Vigraha-vyāvartan̄, consider that the right process to discriminate between beliefs that are knowledge and beliefs that are not is a consensus, whose task is to find an equilibrium between the beliefs one has about the world and successful practice. And, as I said, Nāgārjuna is happy with it, he is not denying this approach but he is indicating that it is in nature coherentist, on-coming from the decision of a scientific community, and not foundational, on-coming from the structure of the world itself.

Therefore, the kind of semantic anti realism we are advocating here is more in line with Brandom's INFERENTIALISM, as outlined in [2], than in line with Dummett's approach, advocated in [3]. The main difference between the two is that Brandom performs what could be called a 'social turn'. According to Brandom, the nature of assertion consists in the fact that in asserting, the speaker achieves the following institutional effect: she undertakes the responsibility of justifying her assertion. Following the lines of Brandom ${ }^{3}$, the important point here is therefore to analyse assertion as commitment. We claim that what Nāgārjuna is saying, though different in nature, is governed by the same rules that govern Brandom's inferentialism, namely:

- The fact that the signification of a proposition cannot be specified independently from the subject who enunciates this proposition ; and a switch from a referentialist semantics to a semantics in terms of conditions of assertability. This is a consequence of Nāgārjuna's position that nothing is independent.

- A conception of the act of assertion in which 'to assert $\varphi$ ' means 'to commit oneself to give justifications for $\varphi$ '. Here, the notion of justification becomes basic. This reading follows from the fact that no position in the Vigrahavyāvartan $\bar{\imath}$ is advocated without the set of all the strategies one could need to defend it. In other words, any position advocated in this work is present along with the set of all the strategies needed to make the point in a given discussion. Notice here that strategies are not the same depending on the identity of the opponent at stake ${ }^{4}$.

The dialogical approach In order to advocate this, we are going to make use of a formalism, namely Dialogical Logic, whose format is very likely to express Nāgārjuna's approach. This formalism is very straightforward, first because of its dialogical presentation ; and secondly for its anti realist motivations. Other conclusive connections will be stressed in the course of this section. The approach of dialogical logic developped by Rahman, as shown by [8], is a modified version of the CONSTRUCTIVIST approach of Lorenz and Lorenzen (Erlangen school), [7] enhanced with a PRAGMATIST orientation. It deals with the features of semantic anti realism just mentioned and measures the signification of a sentence by means of its conditions of assertability, that is to say by means of the set of all the

\footnotetext{
${ }^{3}$ In [2], Chapter 6: 'Objectivity and the Normative Fine structure of Rationality'

${ }^{4}$ For example, reductio ad absurdum arguments are used in the Mūla-madhyamakakārika against an Abhidharmika opponent, while petitio principii arguments are the

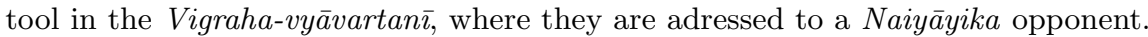


possible strategies when discussing the proposition expressed by the sentence in question.

More precisely, what is at stake in this approach by means of a formal proof is to establish the validity of a sentence (which content is a proposition). Nonformally speaking, a formal proof is a game between two players, respectively called the Proponent and the Opponent, that ends when all the justifications of the sentence at issue are given or when no further move is allowed. The mark of the validity of a sentence is the presence of a winning strategy. There is a winning strategy when the Proponent wins the dialogue whatever the choices of the Opponent may be.

We can already see that a very important feature of this dialogical approach of logic is the asymmetry between the Proponent and the Opponent. Here, only the Proponent is performing genuine assertions. This is due to the 'formal restriction rule' according to which only the Opponent can assert atomic formulas or, to put it in a different way, can assert elementary justifications. It is important to keep in mind here that atomic formulas are the parts of a formula that is not analysable through logical tools. We therefore are unable to prove them logically. Yet, asserting them by presupposing them would be but justifying a proposition within a particular case and, once more, we here deal with validity and the dialogues are formal dialogues. The Dialogical proposal is therefore to allow the use of such an elementary justification if and only if the Opponent has conceded it.

Now, as the Opponent's role is to defeat the Proponent's assertion, he will perform as few concessions as he can and will introduce the minimal set of atomic formulas. Testing the formal justification of a proposition within this type of dialogue is thus like convincing the most acute interlocutor. Hence, when the Proponent wins, the set of plays of the Opponent represent but the construction of the minimal set of presuppositions needed in order to prove the validity of the sentence (in order to assert that a given proposition holds in all situations); they do not represent the moves of a 'real' player. Let us remark here that the builder of the minimal set of conditions of assertability is itself by definition asserting without restriction at all. This is why he is therefore not to be considered as to be performing assertions.

What we will recall of this Dialogical approach for our purpose are the following features:

- A formal proof is put in the form of a dialogue, that is to say of a linguistic interaction. This is part of the pragmatist sensitivity.

- By means of the moves of the pseudo-player Opponent in a dialogical play, asserting a proposition amounts to asserting only the set of its justifications, that is to say, the set of its conditions of assertability. This is a consequence of the constructivist anti realist approach. 
From this, propositions are the forms of an achieved dialogue ${ }^{5}$. Hence, asserting a proposition amounts to asserting the entire dialogue that was used to assert it. As Keiff [6] put it:

The fundamental idea of Dialogical semantics could be enunciated through the following principle:

"The signification of an assertion which has its type entirely given by the form of the dialogue in which it has been asserted by a speaker, provides, for a critical interlocutor, with all the necessary justifications to succeed in his assertion"

Interpreting Nāgārjuna These features of the Dialogical approach lead us to conceive it as a really adapted tool for one who wants to discuss Nāgārjuna's position on theories of assertion. Indeed, if a proposition is a dialogue brought to fruition, then any dialogue whose initial thesis is defective DOES NOT CONTAIN ANY PROPOSITION IN THAT VERY SENSE ${ }^{6}$ because:

To assert is to commit oneself to provide with justifications

And in a formal game, this means to provide with justifications in any situation. In the Indian context, we deal with such a formal game when we speak about the process of the justification of an inference because an inference is a tool to get assured knowledge, that is to say unquestionable knowledge. This universality seems to be exactly what Nāgārjuna refutes when he says:

\section{मदीयमपि वचनाम् प्रतीत्यसमुत्पन्नत्वान् निःस्वभावं ।}

madīyam-api vacanam pratītya-samutpannatvān nihsvabhāvam

$[\mathrm{VV}, \mathbf{v . 2 2}]$

(Nāgārjuna's self commentary on the verse 22.)

My speech, because it is dependent on conditions, is contextual (literally 'is without a self-sufficient nature') $)^{7}$.

Nāgārjuna is saying that the validity of any speech act does always depend on the chosen focus within which I assert. And from this, to prevent oneself from an illusory universal assertion amounts to be aware of the fact that such a formal dialogue can never be finished and, therefore, that there are no proposition in that very sense. And this provides us with a means to understand the famous:

\footnotetext{
${ }^{5}$ This conception is shared by linear logic and ludic logic as developed by Girard and associates (see for example [5]). The study of these frameworks could also be very fruitful to our understanding of Nāgārjuna's position.

${ }^{6}$ Notice here that the Sanskrit expression for 'thesis' is 'siddha-anta', 'what is established at the end'.

${ }^{7}$ In this talk, each quotation of Nāgārjuna is from my own translation, taken from my Master Dissertation, Nāgārjuna et le pluralisme logique, at the University of Lille in September 2004. I had for this translation mainly worked with the edition of E.H.Johnston and A.Kunst, published in 1978 with the excellent translation of Professor Bhattacharya, see [1].
} 


\title{
यदि काचन प्रतिज्ञा स्यान्मे तत एष मे भवेद्दोषः । नास्ति च मम प्रतिज्ञा॥
}

\author{
yadi kācana pratijña syān me tata eșa me bhaved doṣah | \\ nāsti ca mama pratijñ $\bar{a} \|$
}

$[\mathrm{VV}, \mathbf{v . 2 9}]$
If I had asserted any proposition, this fault (consisting in the paradox of self-reference) would be mine,
but I do not assert any proposition.

We are therefore able to say that when Nāgārjuna says that he does not make any assertion, he is not saying that he says nothing, he is very likely to say that he will not commit himself in the formal process of justification of his positions. The reasons of this refusal are that such a formal proof with a universal claim is vain. A formal proof can in no way be complete. Nāgārjuna's sentence ' $I$ do not assert any proposition' can therefore be understood this way 'No sentence is 'valid' in the sense of 'universal". We can speak together and understand what a given language conveys but we have to keep in mind that this is the conventional level, that at every moment things can be discussed and that the one who wants to reach an indisputable claim whatsoever will be defeated.

At the verse 24, Nāgārjuna is performing a terminological switch from pratijña (proposition) to $v \bar{a} d a$. Traditionally, the term $v \bar{a} d a$ refers to the philosophical debate or to a claim in a discussion. Now, he have shown that in these lines, Nāgārjuna is performing a speech act that is not fully justifiable. We therefore propose to render this act by the term 'position' in the sense that it is something that depends on hypothesis, something that is still disputable.

We are going to follow the same line in our understanding of Nāgārjuna's treatment of negation.

\subsection{The art of making no negation}

A constructivist negation... If the negation of a proposition is the assertion of the negated proposition, then this problem also affects the act of negating: the negation of a proposition is always questionable. The problem here is that Nāgārjuna can not firmly establish his criticisms if they are in the negative form.

In verses 61 to 63 , Nāgārjuna explains that negating a thing involves the propositional attitude he wants to get rid of because the act of negating is but the act of asserting the negated thesis. Hence, he has to say:

$$
\begin{aligned}
& \text { प्रतिषेधयामि नाहाम् । } \\
& \text { प्रतिषेधयासीत्यधिलय एष त्वया क्रियते ॥ } \\
& \text { pratiședhayāmi nāham | }
\end{aligned}
$$

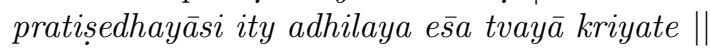

[VV, v.63] 


$$
\begin{aligned}
& \text { I do not negate anything, } \\
& \text { You foolishly calumniate me when you say 'you negate'. }
\end{aligned}
$$

Now the question remains: what sort of speech act is he performing then?

$$
\text { अत्र ज्ञापयते वागसदिति तन्न प्रतिहन्ति ॥ }
$$

atra jñāpayate vāg asad iti tan na pratihanti $\|$

$[\mathrm{VV}, \mathbf{v . 6 4}]$

Here, the speech makes it known as false, it does not negate.

In other words, the attack of a given thesis does not lead to the assertion of the negated thesis, but leads to show that the assertion of the thesis is faulty. What Nāgārjuna performs here is an other type of speech act which does not imply a propositional attitude as the assertion does. We will call this act a DEnEGATION. Characterizing this act is the goal of the following section.

...and the operator of denegation In the Dialogical approach of logic as introduced above, Keiff developed in [6] a negation which encodes a very similar process.

First of all, what is at stake is to understand a type of negative speech act as the indication of the failure of an act of assertion. As such, this is a constructivistlike negation according to which 'non $A$ ' is to be read 'there is no correct proof of $A$ ' and not 'there is a correct proof of non $A$ '. What is more, unhappy with the standard way to encode this reading in a formal proof, that is to say unhappy with the interpretation of 'non $A$ ' as ' $A$ entails a contradiction', Keiff makes a step that will help us here ${ }^{8}$. More precisely, he develops another reading in which 'non A' behaves like an OPERATOR OF DENEGATION and has to be read 'if you assert A, I will show you that your formal proof of $A$ is not sufficient'.

Now, it is evident that this sticks to what is at stake in Nāgārjuna's approach on theory of assertion when he points out the fact that the signification of an assertion is never unchallenging data. Here, it is worth mentioning that Nāgārjuna makes use of reductio ad absurdum arguments, but never uses them in order to establish the opposed thesis. He always uses them in order to show that the attacked thesis is no a justified thesis and that it does not hold. Moreover he does not, in the Mūla-madhyamaka-kārika, develop a whole meta theory about the fact that every thesis can be questionable, but he takes one by one every metaphysical thesis in order to show how they can each be disputed.

\footnotetext{
${ }^{8}$ His motivations were different,since he aimed at introducing a notion of relevance
} that could not be encoded within this standard interpretation. 


\section{$3 \quad$ Nāgārjuna and Buddhist practice}

\subsection{Dialogical Conclusions and the everyday life strategies}

To summarize, Nāgārjuna is saying that we are performing only unfulfilled assertions (respectively negations). Speech acts are never assertions (negations) in the strict sense but positions (denegations). The reason for it is that to assert a proposition in a philosophical discussion is to commit oneself to give the justifications for this proposition in such a manner that it will be unquestionable whoever the interlocutor may be while we have to be aware of the fact that the signification and validity of any sentence have their roots in a net of conditions that cannot be entirely enumerated: an assertion (negation) is always still dependent on a hypothesis that is not justified.

Hence, my claim is to say that Nāgārjuna does not call into question the fact that a set of statements expressing epistemically guaranteed beliefs can possibly be considered as a set of statements expressing 'knowledge' (which would have been a skeptical position). What he does question is rather the origin of this guarantee. According to him, the epistemic guarantee is not the agreement between my set of beliefs and reality, but the agreement between my set of beliefs and the successful practice of a community (which is more like an anti realist position in line with Brandom's inferentialism).

In this reading, the Dialogical approach is useful because (in addition to its dialogical frame directly able to express Nāgārjuna's position) it considers a content of knowledge as the practice of an epistemic agent. This is the idea captured by the fact that 'a proposition is the form of an achieved dialogue' or, in other words, by the fact that 'a proposition is the set of its conditions of assertability by a speaker'. Moreover, the Dialogical approach provides with technical tools to express this conception of a proposition, and to express the fact that if the agreement is to be between my set of beliefs and the successful practice of a community, then there can be several distinct types of agreement. And this is what we are going to develop in this section.

First of all, from the Dialogical perspective, Nāgārjuna's claim amounts to the following claim: 'EVERYTHING IS FALSIFIABLE'. Which is not the same claim as 'everything is false'. It is important to keep in mind the asymmetry between the two players of a linguistic game as captured by a Dialogical game. More precisely, the position of Nāgārjuna could be reformulated in this frame by saying that the Proponent can never have a winning strategy, whether she asserts or denies something. Only the Opponent can have a winning strategy and he always has. There is no achieved dialogue, no more is there a proposition because there is no form of an achieved proof. More formally, let us consider a consequence relation $\models$ (extension to a syntactic derivability relation is straightforward). To say that $\models$ is trivial usually amounts to say that for any well formed formula $\varphi$ and $\psi$, $\varphi=\psi^{9}$. But one could also define a dual concept of triviality, namely that for any $\varphi$ and $\psi, \varphi \not \models \psi$.

\footnotetext{
${ }^{9}$ Equivalently, if $\varphi$ is $\mathrm{T}$ ('top'), this means that any $\psi$ is valid.
} 
If one is to take seriously Nāgārjuna's claim that no assertion is possible, then one cannot escape the conclusion that the logic he advocates is trivial in the second sense, i.e. nothing can successfully be defended against all possible criticisms, not even logical truths for there is not any.

While the whole logic does not seem to allow for a lot of fruitful developments, a fragment of it, namely the fragment in which the Opponent choses to play within a sub class of models (a focus), will do. More precisely, we here deal with a sub system in which there are validities. One can even play within classical rules $^{10}$. The only restriction here is that there are no ultimate validity, that is to say, there are no validity against an Opponent that plays the best possible moves. In other words, the Proponent can never have a winning strategy against an Opponent who plays the best possible moves. But he can perfectly win against a not acute or comprehensive one. This is why we do learn and communicate in everyday life (vyavahāra). The Proponent can win, but he will manage to do so only against an Opponent that grants him concessions. These restrictions are $a d-h o c$ (conventional) and they do define a certain type of Opponent. Nāgārjuna does not develop this, but the Jainas will do in their naya-vāda, their 'theory on perspectives', in which each set of restrictions of the Opponent will represent a given Indian school of thought.

\subsection{The art of making indications}

We have been until now explaining Nāgārjuna's position, but we have not yet come to the defense he performed against the ones who argue that the position that everything is disputable is itself disputable. In order to have another approach to this criticism, I would like to come back to the asymmetry between the Proponent and the Opponent in the Dialogical approach. The Proponent is the only one to have COMMITMENTS when asserting a proposition. Everything 'asserted' by the Opponent, is 'asserted' at the meta theoretical level. More precisely, the status of his pseudo-assertions and pseudo-commitments is nothing else that the indication of what the Proponent needs to justify what he is asserting.

Nevertheless, Nāgārjuna is 'protected' from asserting just as long as he is not trying to defend as a thesis the positions he has in his Vigraha-vyāvartanī because it is evident that the paradox is present whenever what we are performing at the meta theoretical level is played within the propositional level. Nāgārjuna's 'I do not assert any proposition' is precisely the recognition of the fact that if he had put his meta theoretical positions within a discussion for getting justifications, they would have been challenged. Hence, he is not playing them within a philosophical disputation, but he is taking the only means he has, namely practice. Through this practice, he can show for any thesis in a discussion, that this thesis cannot successfully be defended against all possible criticisms, which is the task of the Müla-madhyamaka-kärika. But this is important to keep in

10 This is a counterargument to the thesis according to which Nāgārjuna holds para consistent thesis. 
mind that doing so Nāgārjuna is playing at the 'object language level' in a very poor sense: he only takes the pseudo-interlocutor role of the Opponent and, in each situation, shows how to falsify a sentence (which is certainly not the same thing as trying to establish a negative sentence!). I said 'in a very poor sense' because this role is but the indication of a metalanguage position. The same way, in his Vigraha-vyāvartan̄i, Nāgārjuna stays at the level of the metalanguage to indicate that he will not go at the level of the language object for any (positive or negative) sentence ${ }^{11}$.

\subsection{Buddhist soteriology}

The question is therefore the following: how powerful is the act of Nāgārjuna when he is pseudo-asserting? To answer this, it is useful to keep in mind the deep thesis of John Woods, in [12], according to which a 'fallacy' is not a fault of reasoning. This is rather a reasoning such that there is no best reasoning for men, that is for rational agents with limited capacities.

This thesis takes on a new meaning in this Indian theory. Here, the speech act fails to be an assertion. It is but a position in a debate and holding such a position is not considered as a fault of reasoning: it is the right and fruitful way to conduct a reasoning. Speech acts are useful even if they are not propositions. More precisely, language is useful for one to posit himself or somebody else within another web of conditions, within another perspective from which she will be able to notice and signify other things. Language as a mere conventional activity is useful to posit the interlocutor within a perspective in which she will be able to experience useful things for her emancipation. In this argument, Nāgārjuna uses the parable of an artificial man:

$$
\begin{aligned}
& \text { निर्मितकायां यथा स्त्रियां स्त्रीयम् इत्य असद्राहम् । } \\
& \text { निर्मितक: प्रतिहन्यात् कस्यचिद् एवं भवेद् एतत् ॥ } \\
& \text { nirmitakāyām yathā striyām strīyam ity a-sad-grāham | } \\
& \text { nirmitakah pratihanyāt kasyacid evam bhaved etat } \|
\end{aligned}
$$

$[\mathrm{VV}, \mathbf{v . 2 7}]$

(Nāgārjuna's self commentary of the verse 27.)

$<$ What I am doing with my speech $>$ is as if an artificial man would prevent from the wrong perception of a man <who would believed $>$ 'this is a woman' where there is an artificial woman

Now, the fault occurring at the semantic level is present at the practical level too : if the assured character of an assertion is something debatable in the object language and if the metalanguage can be put and played within the object language, then it is the target of the same objections and we can not know with

${ }^{11}$ Here we can think about Tarski's work in which he explains that the object language is strictly included within the metalanguage precisely because of such situations, [10]. 
certitude this metatheoretical fact, for example, that we are progressing in our knowledge.

Our proposal here is to say that this is precisely why we have to practice. More precisely, we can not assert in a propositional way that we are progressing, and it is important not to do so, but we can experience it.

That is why Nāgārjuna do not go further in its theory of assertion. Following the example of the Buddha, remaining silent on metaphysical questions is a crucial step for him to undergo ${ }^{12}$. In conclusion, our claim is that even if it is not developed, the technical and philosophical consequences of such a position are:

- A theory of assertion as act of commitment ; and a theory of the forces of the assertion (assertion versus position, and negation versus denegation).

- To redefine the role attributed to logic. More precisely, it seems that what is at stake is the transition:

- From a vision of inference (inductive and deductive) as what legitimates the fact that a proposition is considered as an assured knowledge

- To a vision in which argumentation has the pragmatic function to validate some inferences in relation to a given perspective.

\section{References}

1. B.K.Bhattacharya. The Dialectical Method of Nāgārjuna: Vigraha-vyāvartan̄̄. Motilal Banarsidass Publishers, Delhi, 1998 (first ed.1978).

2. R.B.Brandom. Articulating Reasons: An Introduction to Inferentialism. Harvard University Press, Cambridge, 2000.

3. M.Dummett. The Logical Basis of Metaphysics. Harvard's university Press, Cambridge, Massachussetts, 1991.

4. J.L.Garfield. 'Dependent Arising and the Emptiness of Emptiness: Why Did Nagarjuna Start with Causation?'. Philosophy East and West, vol. 44, No. 2, pp. 219-250, 1994.

5. J.Y.Girard. 'Linear Logic'. In Theoretical Computer Science, vol.50, pp.1-101, 1987.

6. L.Keiff. Le Pluralisme Dialogique: Approches Dynamiques de l'Argumentation Formelle. Phd-Thesis, Lille, December, 2007.

7. K.Lorenz and P.Lorenzen. Dialogische Logik. WBG, Darmstadt, 1978.

8. S.Rahman and L.Keiff. 'On how to be a Dialogician'. In D.Vanderveken (ed.), Logic, Thought and Action. Springer Verlag, Dordrecht, pp.359-408, 2005.

9. M.Siderits. 'Nāgārjuna as antirealist'. In Journal of Indian Philosophy, vol.16, No.4, December, p.311, 1988.

10. A.Tarski. Logic, Semantic,Metamathematics. J.Corcoran (ed.), Hackett, 1983 (Second ed.).

11. I.Waldo. 'Nāgārjuna and analytic philosophy' (2). In Philosophy East and West, vol. 28, No. 3., July. Hawaii's university Press, Hawaii, pp.287-298, 1978.

12 This metaphysical Buddhist silence of Nāgārjuna is close in spirit to Wittgenstein's silence in L.Wittgenstein, in [13]. 
12. J.Woods. Paradox and paraconsistency: Conflict resolution in the abstract sciences. Cambridge University Press, Cambridge, 2002.

13. L.Wittgenstein. Philosophical Investigations. G.E.M.Ascombe (transl.). Blackwell, Oxford, 1958.

\author{
Marie-Hélène Gorisse \\ Department of Philosophy \\ University of Lille 3 \\ 59000 Lille \\ France \\ mhgorisse@gmail.com
}

